\title{
On the ferrocyanides of strychnia and brucia
}

\section{M.D. Brandes}

To cite this article: M.D. Brandes (1849) On the ferrocyanides of strychnia and brucia, Philosophical Magazine Series 3, 34:228, 238-239, DOI: 10.1080/14786444908646220

To link to this article: http://dx.doi.org/10.1080/14786444908646220

册 Published online: 30 Apr 2009.

6 Submit your article to this journal $\pi$

Џll Article views: 2

Q View related articles $₫$ 
Muromontite.-By this name the author designates a ceriferous mineral met with in the environs of Mauersberg near Marienberg, in the Erzgebirge. It has the form of blacik grains, with a greenish reflexion. Density, $4 \cdot 263-4 \cdot 265$.

This mineral contains-

\begin{tabular}{|c|c|}
\hline lica & $31 \cdot 089$ \\
\hline Yttria & $37 \cdot 140$ \\
\hline Glucina & $5 \cdot 510$ \\
\hline Alumina. & $2 \cdot 230$ \\
\hline Oxide of lanthanium. & $3 \cdot 530$ \\
\hline Oxide of cerium... & $5 \cdot 540$ \\
\hline Protoxide of iron ... & $11 \cdot 230$ \\
\hline Protoxide of manganese. & 0.900 \\
\hline Lime & 0.710 \\
\hline Magnesia & 0.420 \\
\hline Soda & $0 \cdot 650$ \\
\hline Potash .. & $0 \cdot 170$ \\
\hline Water . & 0.820 \\
\hline & \\
\hline
\end{tabular}

Journ. de Ph. et de Ch., Novembre 1848.

\section{ON THE FERROCYANIDES OF STRYCHNIA AND BRUCIA. BY M. D. BRANDES.}

The auther states that when a solution of ferrocyanide of potassium is added to one of a neutral salt of strychnia, an abundant precipitate is obtained, consisting of small and nearly colourless needles.

In operating on dilute solutions deprived of free acid, crystals of two to three centimetres in length and of a very bright yellow colour are obtained; they are four-sided prisms, terminated by dihedral summits : these crystals are ferrocyanuret of strychnia, represented by the formula $2(\mathrm{Str}, \mathrm{H} \mathrm{Cy})+\mathrm{Fe} \mathrm{Cy}+8 \mathrm{HO}$. At $212^{\circ}$ the salt loses 6.1 per cent, or six equivalents of water. . If it be dissolved in hot water, or if the cold saturated solution be boiled, crystals of strychnia separate, and the liquor, which is of a deep yellow colour, holds ferrocyanide of strychnia in solution,

$$
3(\mathrm{Str}, \mathrm{HCy},)+\mathrm{Fe}^{2} \mathrm{Cy}^{3}+12 \mathrm{HO} \text {. }
$$

This salt, which forms crystals of a golden-yellow colour, corresponds to the red prussiate of potash, and may also be obtained by mixing the cold saturated solutions of sulphate of strychnia and red ferrocyanide of potassium : according to the author, this salt loses three equivalents of water in a dry vacuum, six equivalents at $212^{\circ}$, and eight equivalents at $277^{\circ} \mathrm{F}$. Above this temperature it decomposes. When an alcoholic solution of strychnia is mixed with a solution of hydroferrocyanic acid in alcohol, a white amorphous precipitate is obtained. This is nearly insoluble in water or alcohol, and has a distinct acid reaction. M. Brandes assigns to it the formula (Str, $2 \mathrm{ACy}+2 \mathrm{Fe} \mathrm{Cy})+5 \mathrm{HO}$. He considers it as an acid analogous to the hydroferrocyanic, and expresses its constitution as follows, deducting the five equivalents of water it contains $(\mathrm{Str}, \mathrm{HCy}$ 
$+2 \mathrm{Fe} \mathrm{Cy})+\mathrm{HCy}$; the author has not, however, as yet succeeded in preparing salts directly with this acid.

The ferrocyanurets of brucia are prepared by processes analogous to those above described; they resemble, both in their properties and composition, the corresponding salts of strychnia. - Ibid. Janvier 1849.

\section{METEOROLOGICAL OBSERVATIONS FOR JAN. 1849.}

Chisurick.-January 1. Overcast : hazy. 2. Clear and frosty. 3. Frosty : dry haze: overcast : frosty. 4. Uniformly densely overcast : rain. 5. Drizzly and foggy. 6. Overcast. 7. Overcast : rain at night. 8. Rain. 9. Very fine : slight rain. 10. Cloudy: boisterous: rain. 11. Rain: densely clouded. 12. Frosty : overcast: rain. 13. Densely clouded: rain, 14. Rain, 15. Clear. 16. Fine : rain. 17. Rain : densely overcast : clear. 18. Fine: boisterous at night. 19,20 . Very fine. 21. Very fine : overcast : boisterous. 22. Boisterous : fine : clear and boisterous. 23. Densely clouded : fine. 24. Cloudy : boisterous at night. 25. Densely clouded : boisterous. 26. Rain : exceedingly fine. 27. Slight frost: overcast : rain. 28. Cloudy : fine. 29. Rain: cloudy and cold : frosty at night. 30. Slight fog: drizzly. 31. Fine : clear and frosty at night.

Mean temperature of the month ............................ $39^{\circ} \cdot 56$

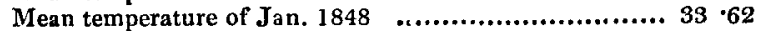

Mean temperature of Jan. for the last twenty years ...... $36 \cdot 40$

Average amount of rain in Jan. ......................... 1.59 inch.

Boston. - Jan. 1. Cloudy. 2-4. Fine. 5, 6. Cloudy. 7. Fine : rain early A.M. 8. Rain. 9. Fine : rain 8. $M$. 10. Cloudy : stormy all day. 11. Cloudy : rain early A.M. 12. Fine. 13. Rain : rain early A.M. 14. Cloudy : rain early A.M. 15. Fine : rain A.M. and P.M. 16. Foggy, 17-20. Fine. 21. Cloudy. 2224. Fine. 25. Cloudy. 26. Fine: rain early A,M. 27 . Fine: rain P.M. 28. Fine. 29. Rain : rain A.M. 30. Cloudy : rain A.M. and P.M. 31. Fine.

Applegarth Manse, Dumfries-shire.-Jan. 1. Frost moderate. 2. Frost very hard : barometer falling. 3. Frost clear: fine. 4. Frost, but cloudy. 5. Frost : cloudy. 6. Frost : still cloudy. 7. Frost : still more overcast. 8. Thaw : rain : fog : rain again. 9. Frost again : clear A.M. : rain P.M. 10. Heavy rain during night : rivers flooded. 11. Frost A.M. : thaw at noon: rain. 12. Soft rain all day. 13. Soft rain : cleared : rain r.m. 14. Gentle frost : cloudy : wind rose, 15. Soft : cloudy, 16. Mild and clear after rain A.M. 17. Moist A.M. : rain and high wind $P, M$. 18. Very fine till noon : rained again, 19. Frost: getting cloudy P.M. 20 . Heavy rain and high wind P.M. : thunder. 21. Stonn of wind and rain, 22. Fair, but a storm of wind. 23. Fair A.M. : came on storm, wind and rain. 24. Rain nearly all day : wind high. 25. Fair and keen A.M. : wet r.M. : high wind. 26. Fair A.M.: rain P.M. 27. Snuw : rain: wind high. 28. Frost : clear: dull r.M. 29. Frost and snow : thaw and rain. 30. Frost moderate. 81 . Thaw and showery.

Mean temperature of the month .......................... $36^{\circ} .85$

Mean temperature of Jan. 1848 .............................. $93 \cdot 80$

Megan temperature of Jan. for the last twenty-five years . $34 \cdot 90$

Rain ........................................................ 8.70 inches,

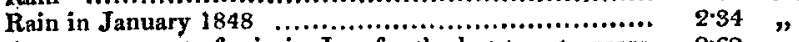

Average amount of rain in Jan. for the last twenty years 2.60 ",

Sandwick Manse, Orkney.-Jan. 1. Cloudy. 2. Bright : eloudy. 3. Cloudy. 4. Cloudy : frost; snow-showers. 5. Bright : cloudy. 6. Snow, 7. Thaw : clear. 8. Rain : showers. 9. Showers: eloudy. 10. Rain : snow. 11. Snow. 12. Rain : showers. 13. Showers. 14. Showers : sleet-showers. 15. Showers. 16. Showers: cloudy. 17, 18. Showers. 19. Showers : clear. 20. Cloudy. 21. Rain : showers. 22. Sleet-showers. 23. Sleet-showers : rain. 24. Rain*: sleet-showers : cloudy. 25. Sleet-showers : aurora. 26. Sleet-showers: cloudy. 27. Bright : sleet-showers. 28. Sleet-showers : clear. 29. Frost : cloudy. 30. Snow : sleet: showers. 31. Sleet-showers: showers. fell.

* From 9 P.M. on 23 rd till 2 P.M. on 24th (about 17 hours) 2.08 inches of rain 